\title{
Status and Infrastructure of the Health Sector in Karnataka
}

\author{
Siddu V H*, Keshava Murthy K D† and R Revankarł
}

\begin{abstract}
Karnataka is closer to the average of India in case of health status and health facilities, but compared to the states like Kerala, it stands too low. The most striking problem, related to the health infrastructure and health status arises out of the regional imbalance. The study shows that the Gulbarga and Belgaum divisions of Karnataka show a poor status in health infrastructure and health status. Among these, the Gulbarga division (means Hyderabad Karnataka) lies in the lower position. It is well known that Hyderabad Karnataka is underdeveloped in most of the sectors compared to the rest of the regions. Lesser health infrastructure facilities in this region clearly indicate the neglect of the government intervention/ interest to develop basic infrastructure facilities in this region. For better health, health facilities should be improved. For better health facilities, public health expenditure is very important. At present, the Karnataka government is spending very less amount of money on health, which is about 2 per cent of the NSDP. This amount has to be increased. Increasing the public expenditure alone, cannot serve the purpose, unless it is
\end{abstract}

\footnotetext{
* Assistant Professor, Centre for Multi-disciplinary Development Research (CMDR), Dharwad; shiddu22@gmail.com

† Lecturer, St Joseph's College of Arts and Science, Bangalore; keshav.thesplendidsurprise@gmail.com

‡ Research Assistant, Centre for Multi-disciplinary Development Research (CMDR), Dharwad; drr.cmdr@gmail.com
} 
properly used for delivering quality infrastructure and good service mechanization.

Keywords: Health Sector, Health Infrastructure.

\section{Introduction}

The importance of the good health of people cannot be minimized, as it has been considered as one of the most important components of the human capital. Good health is an indication of a strong mind. Due to its vital importance, the economics of health is attracting researchers and policy makers more rapidly in the recent decades. It is well said in the theory of the human capital that people should invest themselves in terms of education, health and skill development programmes. Health is a major segment of the human capital. If the quality of the human capital is not good, then the physical capital and natural resources cannot be utilized properly and the growth can neither be sustained nor be qualitative.

Life expectancy at birth, infant mortality rate, fertility rate, crude birth rate is perhaps the best measures of the human capital. These indicators of health are determined by numerous factors such as per capita income, nutrition, housing, sanitation, safe drinking water, social infrastructure, health and medical care services provided by the Government, geographical climate, employment status, incidence of poverty and so on (Dadibhavi and Bagalkoti, 1994). However, in the developing countries like India, due to poor financial accessibilities, it is very difficult for the people to spend money. Hence, the intervention of the Government is necessary for making strong human capital and sustained economic growth as they are strongly and positively inter-related.

Though India stands on par with the leading countries in terms of population concentration, its health status is far behind the satisfactory level compared to the other developing countries. It is needless to point out that, this is due to the lack of proper budgetary allocation and poor infrastructure facilities. It is disappointing to note that India's public expenditure as a share of GDP as well as a share of total budget is low compared to many other developing countries. 
Further, the biggest challenge for the Indian health sector is that it has to not only sustain quality but also reduce the regional disparities in health status and infrastructure, which is also observed in other sectors like economic growth, human development, and standard of living and so on. Notable studies have traced out many interesting realities with respect to the status and infrastructure in the health sector disparities in India.

Karnataka state is not an exception to this kind of disparities. Though studies on regional disparities in health sectors of Karnataka are rare to find, nevertheless some of the scholarly studies done by Panchamukhi and others have brought out the inter-district disparities in the health sector. They held that the disparities have been constantly increasing over a period of time and suggested for the higher public spending on the same. However, it is hard to find a comprehensive study which analyzes the intra-state disparities on health and Government financing in recent days. In the light of the above, in the present study, an attempt has been made to analyze the regional imbalance in the health sector in the state and public expenditure on health in Karnataka.

The study has been divided into five sections. Apart from the introduction, section II discusses the status and infrastructure with respect to health in Karnataka. Further, in section III regional disparity in health infrastructure and status have been discussed and in section IV, public expenditure on health sector is analysed. Section $\mathrm{V}$ concludes the present paper with appropriate findings and suggestions.

\section{Health Status and Infrastructure: A Comparison between Karnataka and India:}

Before discussing the health status in Karnataka, a quick look at the comparisons of some of the important health indicators of India, with the rest of the regions of the world would give the best picture of India's health status with the rest of the world. The data related to the indicator, shows that (Table 1), Life expectancy at birth (LEB) in India, is the lowest among the average of all regions, except the 
average of the 'least developed countries', 'low human developed countries' and 'Sub-Saharan Africa'. It is disappointing to note that LEB in India is also lower than the average of SAARC (South Asia) countries. Countries with high human development have the LEB of 80 years, whereas it is only 65.4 years in India, which is 1.2 times lower than the other countries in the world. Life expectancy at birth is a commonly used indicator, as it is the proxy for overall health condition/status and availability of the health facilities for the people in a country. Another important indicator presented in the table is the 'under five mortality'. In this indicator also, the Indian pattern can be observed as it was in LEB. 'Maternal mortality ratio' of India is 230, which is 15 times higher than that of the very high human developed countries (15.5). It is pointless to mention that this is due to the lack of health facilities, which has resulted due to the government spending less on this sector. Health expenditure as a share of GDP is 4.2 per cent, which is the lowest among the average of all regions except the SAARC countries. The point to be noted here is that the health expenditure in India is not too high as compared to the average of SAARC courtiers; it is only 0.01 point per cent higher than the SAARC countries. Not surprisingly, the per capita GDP of India is much lesser than that of the developed countries. If the health expenditure as a share of GDP is concerned, it shows lower difference, whereas in per capita terms it shows a higher difference between developed and developing countries like India.

Many decades have rolled out since the independence of our country. India is marching towards development in various sectors. It is observed that even though significant improvements have been made under the health sector, they are not satisfactory. Health has been categorised in the state list by the Indian constitution. For many years / decades, the Central Government has not taken any notable policy / programmes. After recognising the importance of health and the lower status of India's health sector - the Central Government has started investing a huge amount of money on the health sector, to fulfil the Millennium Development Goals of Health, especially after the reform period. 
Table 1: Comparison of India, With the Rest of the World as Far as The Health Indicators is Concerned.

\begin{tabular}{|c|c|c|c|c|}
\hline Regions & $\begin{array}{l}\text { Life } \\
\text { expectancy at } \\
\text { birth }\end{array}$ & $\begin{array}{l}\text { Under Five } \\
\text { Mortality }\end{array}$ & $\begin{array}{l}\text { Maternal } \\
\text { mortality } \\
\text { ratio }\end{array}$ & $\begin{array}{l}\text { Total expenditure } \\
\text { on health ( } \% \text { of } \\
\text { GDP) }\end{array}$ \\
\hline India & 65.4 & 66 & 230 & 4.2 \\
\hline $\begin{array}{l}\text { Very high human } \\
\text { development }\end{array}$ & 80 & 6.2 & 15.5 & 11.2 \\
\hline $\begin{array}{l}\text { High human } \\
\text { development }\end{array}$ & 73.1 & 19 & 51.1 & 6.7 \\
\hline $\begin{array}{l}\text { Medium human } \\
\text { development }\end{array}$ & 69.7 & 44.2 & 134.9 & 4.5 \\
\hline $\begin{array}{l}\text { Low human } \\
\text { development }\end{array}$ & 58.7 & 117.5 & 532.2 & 5.1 \\
\hline Arab states & 70.5 & 48.8 & 191.8 & 5.3 \\
\hline $\begin{array}{l}\text { East Asia and the } \\
\text { pacific }\end{array}$ & 72.4 & 26.1 & 79.4 & 4.3 \\
\hline $\begin{array}{l}\text { Europe and central } \\
\text { Asia }\end{array}$ & 71.3 & 19.1 & 29.1 & 6.3 \\
\hline $\begin{array}{l}\text { Latin America and } \\
\text { the Caribbean }\end{array}$ & 74.4 & 22.4 & 79.9 & 7.6 \\
\hline $\begin{array}{l}\text { South Asia } \\
\text { (SAARC) }\end{array}$ & 65.9 & 69.3 & 251.9 & 4.1 \\
\hline $\begin{array}{l}\text { Sub-Saharan } \\
\text { Africa }\end{array}$ & 54.4 & 129 & 618.9 & 6.2 \\
\hline $\begin{array}{l}\text { Least developed } \\
\text { countries }\end{array}$ & 59.1 & 120.1 & 537.1 & 5.6 \\
\hline $\begin{array}{l}\text { Small island } \\
\text { developing states }\end{array}$ & 69.6 & 57 & .. & 7 \\
\hline World & 69.8 & 58.4 & 175.6 & 6 \\
\hline
\end{tabular}

Source: India Human Development Report 2011

infrastructure facilities are lower in India, when compared to many other countries. In the below mentioned table, selected Health status and infrastructure of Karnataka has been compared with that of India. Karnataka is nearer to the average of India in terms of state income and most of the developmental indicators. Similarly, with regard to the health related indicators also, Karnataka's position is above the satisfactory level. Except health expenditure by public and private, in all the selected indicators Karnataka's performance is better than the average of India. 
Table 2: Selected Health Indicators in Karnataka and India

\begin{tabular}{|c|c|c|c|}
\hline $\begin{array}{l}\text { Sl. } \\
\text { No. }\end{array}$ & Items & $\begin{array}{c}\text { Karnata } \\
\text { ka }\end{array}$ & India \\
\hline \multicolumn{4}{|c|}{ I. Status } \\
\hline 1 & Life Expectancy at Birth & 65.3 & 63.5 \\
\hline 2 & Infant Mortality Rate & 41 & 50 \\
\hline 3 & Under Five Mortality Rate & 54.7 & 74.3 \\
\hline 4 & $\begin{array}{l}\text { Percentage of persons not expected to survive } \\
\text { beyond the Age of } 40 \text { years }\end{array}$ & 14.6 & 17.7 \\
\hline 5 & $\begin{array}{l}\text { Percentage of Women Adult Population with BMI } \\
<18.5\end{array}$ & 35.5 & 33 \\
\hline 6 & $\begin{array}{l}\text { Percentage of Men Adult Population with BMI } \\
<18.5\end{array}$ & 33.9 & 34.2 \\
\hline 7 & Percentage of Women with Anemia & 51.5 & 55.3 \\
\hline 8 & Percentage of Children (0-5 years) with Anemia & 70.4 & 69.5 \\
\hline 9 & Death Rate & 7.2 & 7.3 \\
\hline 10 & $\begin{array}{l}\text { Public Expenditure on Health as a percentage to } \\
\text { GSDP }\end{array}$ & 0.87 & 2.02 \\
\hline 11 & Per capita Public Expenditure on Health & 233 & 1014 \\
\hline 12 & Per capita Private Expenditure on Health & 597 & 1639 \\
\hline 13 & $\begin{array}{l}\text { Public Expenditure on Health as a percentage to } \\
\text { total Health Expenditure }\end{array}$ & 71.9 & 58.3 \\
\hline 14 & $\begin{array}{l}\text { Private Expenditure on Health as a percentage to } \\
\text { total Health Expenditure }\end{array}$ & 28.1 & 41.7 \\
\hline \multicolumn{4}{|c|}{ II. Infrastructure Facilites per 10 lakh Population } \\
\hline 1 & Public Health Centres (PHCs) & 38 & 21 \\
\hline 2 & Sub Centres & 140 & 129 \\
\hline 3 & Community Health Centres (CHCs) & 6 & 4 \\
\hline 4 & Rural Hospitals & 8 & 6 \\
\hline 5 & Urban Hospitals & 8 & 3 \\
\hline 6 & Total Hospitals & 16 & 10 \\
\hline 7 & Total Beds & 1096 & 476 \\
\hline 8 & No. of Doctors at PHCs & 48 & 21 \\
\hline 9 & No. of Health Assistants at PHCs & 34 & 31 \\
\hline 10 & No. of Health Workers at PHCs & 203 & 188 \\
\hline
\end{tabular}

Source: India Human Development Report 2011 
Life expectancy at birth (LEB) in Karnataka is 65.3 years, which is comparatively very less than the states like Kerala. In Karnataka, 41 infants die before 3 weeks in every 1000 live birth. Further, 55 children per 1000 live birth, die before the age of 5 . This child/infant death is due to unhealthy pregnancy, underage pregnancy, lack of institutional delivery, ignorance and so on. More than one third of the people are below 18 BMI (Body Mass Index). Female $<18 \mathrm{BMI}$ is 35.5 per cent and Male $<18 \mathrm{BMI}$ is 33.9 ; means the women are more undernourished than the men. After giving women an idol status in the country, it is discouraging to note that more than 55 per cent of the women have anemia, which shows the wretchedness of the women in our country. In Karnataka, the condition is equally worse with 51 percent of the female population being anemic. This female anemia affects the children when the women give birth and nourish them. Hence anemic children (0-5 years) are 70.4 per cent. The above figures clearly show the pathetic condition of the health status in India. On one side, we are talking about IT, BT, double digit growth rate, Swabhimani India, India shining and so on, whereas, in the other extreme, the undernourished child's health has not been taken care of. Lower health status of Karnataka is also due to lower public and private expenditure on health sector. Health infrastructure facilities can be improved through the public expenditure rather than the private expenditure.

Improvements in the health facilities will facilitate better health condition. Information related to health infrastructure facilities of India and Karnataka has also been presented in the table. It can be observed that Karnataka is better off with respect to all the health infrastructure facilities. But these facilities are very less compared to the present health status and the existing population. In Karnataka, there are only 38 Public Health Centres [PHCs] per 10 lakhs population, 140 sub centres and 6 community health centres per 10 lakhs population. The gap between the rural and urban hospitals is high. There are only 6 hospitals per 10 lakhs rural population and 21 hospitals for urban population. In case of beds, per 10 lakhs population, it is observed that there are 1096 beds per 10 lakhs population, which is very less. Doctors per 10 lakhs population in PHCs are only 48 and there are 34 assistants and 203 
health workers for the same amount of population in the state. In our country/state, the number of infrastructure facilities are not only low but also, the services provided in these facilities are also low, which has been empirically proved by many studies. However, the present study analyses the district wise availability of health facilities and health status, and the regional imbalances in the health sector have also been considered as the major objective rather than the quality of services, which can be seen in the following sections.

\section{Regional Imbalances in Health Infrastructure and Health Status:}

Regional imbalance is a common phenomenon faced by every country/states in most of the sectors. Health sector is not an exception for this. Before analyzing the inter-district disparities of the health sector in the state, a brief discussion of inter-division disparities gives a clear picture of the distribution of health facilities and health status among the four administrative divisions. Information related to this has been presented in the below mentioned table. It is generally observed that the district hospitals possess the advanced health infrastructures and equipments when compared to the lower divisions and these results in them saving many lives. For example, during the time of severe injuries or epidemic diseases, patients need an emergency treatment in a well equipped hospital. Such facilities cannot be expected in a Primary Health Centre (PHC) or a Community Health Centre (CHC). Hence, these patients should be taken to the district hospitals (or a similar hospital). However, if these hospitals are situated in faraway places, it may be extremely difficult to save their lives. Hence, it is not only the matter of the number of hospitals but at the same time, the distance and the distribution of the hospitals in different regions/places should also be taken care of. Table 3 reveals that in Karnataka, there is only 1.1 district and other hospitals for every 10 lakhs population. Observing the distribution between North and South, it is found that there are 1.3 hospitals in South Karnataka and 1.0 hospital in North Karnataka per 10 lakhs population. Further, it is also found that the table that in both the indicators shows North Karnataka has lesser number of hospitals 
per 10 lakhs population than the South. Mysore and Belgaum divisions stand first and the last respectively with regard to the health facilities. Looking at them area wise, there are 3.6 hospitals per every 10 thousand Sq. km. area in Karnataka. The number of hospitals in South Karnataka (4.7) is twofold higher than that of North Karnataka (2.5). In this indicator, the Bangalore division stands first with 5.4 hospitals and Gulbarga is at the last position with 2.5 hospitals.

Community Health Centres (CHCs) have comparatively less number of equipments and man power than the district hospitals. They also provide many of the health services and can be most commonly found in the taluk head quarters. Karnataka has 5.3 $\mathrm{CHC}$ for every 10 lakhs population. Mysore division has the highest number of CHCs (7.4 per 10 lakhs population) among the divisions and Bangalore stands at the lowest with 3.4 CHCs per 10 lakhs population. South Karnataka has both the higher and lower number of $\mathrm{CHC}^{\prime}$ s divisions, but the number of $\mathrm{CHCs}$ per 10 thousand Sq. Km. area is high in South Karnataka only. Totally there are $16.9 \mathrm{CHC}^{\prime} \mathrm{s}$ in the state per 10 thousand Sq. Km. area. Mysore and Belgaum are in the first and last positions respectively.

Primary Health Centres (PHCs) have been introduced with the objective of providing better health facilities to the rural population. However, unlike the district hospitals these centres have not been fully equipped. Nevertheless, they have a crucial role in making the people in the rural community aware of their health and to take care of the minor diseases. At the state level, there are 169 PHCs per 10 lakhs population with the distribution of 184 and 149 PHCs in the South and North Karnataka. Mysore division stands first and Bangalore stands last with regard to the same. Looking at the number of hospitals per 10 thousand Sq. Km. area it is found that there are 539 PHCs in the state. Further, North Karnataka has only 394 PHCs and South Karnataka has 693 PHCs for the same amount of the area, which is 1.8 times higher. The Mysore division has 783 PHCs and the Gulbarga division has 365 PHCs per 10 lakhs Sq. Km. area. PHCs are the major source for the rural health care, hence less number of PHCs in an under 
developed division like Gulbarga demands immediate concern from the Government.

Table 3: Divisionwise Selected Health Infrastructure Facilities in Karnataka, 2010

\begin{tabular}{|c|c|c|c|c|c|c|c|c|}
\hline & Item & Belgaum & Gulbarga & Bangalore & Mysore & North & South & Karnataka \\
\hline & & & & Facilities & & & & \\
\hline & District and & 0.9 & 1 & 1.2 & 1.4 & & & \\
\hline & $\begin{array}{c}\text { other } \\
\text { Hospitals }\end{array}$ & -4 & -3 & -2 & -1 & 1 & 1.3 & 1.1 \\
\hline & Community & 5.5 & 6.5 & 3.4 & 7.4 & 50 & 48 & 53 \\
\hline 刍. & $\begin{array}{l}\text { Health } \\
\text { Centres }\end{array}$ & -3 & -2 & -4 & -1 & 5.9 & 4.8 & 5.3 \\
\hline 흥 & PHCs and & 154 & 142 & 135 & 271 & & & \\
\hline & $\begin{array}{l}\text { Sub } \\
\text { Centres }\end{array}$ & -2 & -3 & -4 & -1 & 149 & 184 & 169 \\
\hline & & 764 & 789 & 737 & 1196 & & & \\
\hline & Total Beds & -3 & -2 & -4 & -1 & $7 / 5$ & 901 & 847 \\
\hline & District and & 2.6 & 2.5 & 5.4 & 3.9 & & & \\
\hline & $\begin{array}{c}\text { other } \\
\text { Hospitals }\end{array}$ & -3 & -4 & -1 & -2 & 2.5 & 4.7 & 3.6 \\
\hline$\vec{E}$ & Community & 14.9 & 16.6 & 15.5 & 21.4 & 15 & 100 & 160 \\
\hline $\begin{array}{ll}0 & 0 \\
0 & 0 \\
0 & 0\end{array}$ & Centres & -4 & -2 & -3 & -1 & 10.0 & 10.2 & 10.9 \\
\hline$\underline{\Sigma} \Sigma$ & PHCs and & 418 & 365 & 614 & 783 & 304 & 603 & 530 \\
\hline$\ddot{v}_{2}$ & $\begin{array}{l}\text { Sub } \\
\text { Centres }\end{array}$ & -3 & -4 & -2 & -1 & 394 & 093 & 539 \\
\hline & & 2070 & 2019 & 3337 & 3455 & & & \\
\hline & Total Beds & -3 & -4 & -2 & -1 & 2047 & 3392 & 2701 \\
\hline & & & & Status & & & & \\
\hline Infa & ant mortality & 47.6 & 47.3 & 38.4 & 42.7 & 175 & 404 & 132 \\
\hline & rate & -1 & -2 & -4 & -3 & $4 / .5$ & 40.4 & 43.3 \\
\hline Life & expectancy & 65.6 & 66.6 & 68.6 & 67.4 & 66 & 681 & 672 \\
\hline & at birth & -4 & -3 & -1 & -2 & 00 & 08.1 & $0 \% .2$ \\
\hline
\end{tabular}

Note: Figures in the Parenthesis are Ranks; Source: Computed from the data available from Karnataka at a Glance

Another indicator considered in the study is the number of beds available in the hospitals. Many diseases require a prolonged treatment. Thus, to have better and hygienic bed facilities also have an impact on the health of a patient. Karnataka has 169 beds per 10 lakhs population. In this indicator also, South Karnataka is in a good position than North Karnataka. In South Karnataka, there are 901 beds and in North Karnataka, there are only 775 beds per 10 lakhs population. The Mysore division, with 1196 beds per 10 lakhs population stands in the first position and the Bangalore 
division with 737 beds for the same amount of population stands in the last position. In case of beds per 10 thousand Sq. Km. area, there are 2701 beds in the state, and the North region is in the lower position than the South. Mysore and Gulbarga are in the first and last positions respectively.

The objective of the public health expenditure is to enhance the health infrastructure facilities to improve the health condition of the people. Similar to the health infrastructure, health status is also unequally distributed among the districts. Life expectancy at birth (LEB) is an important indicator to measure the health status of the community. In fact UNDP uses this indicator for the construction of the human development index (HDI) for all countries as a proxy of the health status. However, if data on LEB is not available then the Infant Mortality Rate (IMR) is used for the measurement of the health status. LEB is 67.2 years in the Karnataka state. People of South Karnataka live 2 years more than those in North Karnataka. LEB of Bangalore division is 68.6 years, which is more than the divisions, followed by the Mysore division (67.4 years), Gulbarga division (66.6 years) and Belgaum division (65.5 years). On the other hand IMR in Karnataka is 43.3, which means, 43.3 kids die per 1000 infants. North Karnataka (47.5) has higher infant death than the South (40.4). The ranks of division of IMR are adverse to LEB. Belgaum division is in the first position followed by Gulbarga, Mysore and Bangalore divisions. In Tables 4 and 5, district-wise indicators on health infrastructure facilities and health status indicators are presented. Descriptions of these tables are given below.

\section{Health Infrastructure Facilities Per Ten Lakhs Population}

Among the districts that have higher number of district hospitals, except Kodagu and Kolar, the remaining districts viz. Gadag, Bellary, Dharwad are from North Karnataka. Except Tumkur, the remaining districts of lower order are from North Karnataka. They are Belgaum, Gulbarga, Raichur and Bagalkot.

Except Uttar Kannada, in the top order, the 4 districts in the Community Health Centres (CHCs) are from South Karnataka. 
They are Kodagu, Hassan, Chitradurga and Chikkamagalur. In case of the lower order, the 4 districts, namely Bangalore rural, Bangalore urban, Davngere and Kodagu except Dharwad are from South Karnataka.

The Top 5 districts viz. Kodagu, Hassan, Chitradurga, Udupi and Chamarajanagar are from South Karnataka, which have a higher number of PHCs. Except Bangalore urban, the remaining 4 districts namely, Dharwad, Raichur, Gulbarga and Bellary are the districts which have a lower number of PHCs, and they are from North Karnataka.

Among the top 5 districts which have a higher number of beds, except Uttar Kannada, the remaining districts namely Kodagu, Davangere, Chikkaballapur and Mysore are from South Karnataka. Among the lower order 5 districts, along with Bangalore rural \& urban from the South region, and the remaining three districts namely Bagalkot, Belgaum and Raichur are from the North Karnataka region.

\section{Health Infrastructure Facilities per Ten Thousand Sq. Km. area}

More number of district hospitals are placed in Dharwad and Bellary of North Karnataka followed by Davangere, Bangalore rural, Bangalore urban are from the South region. Among the 5 lower order districts, except Belgaum, Gulbarga, the remaining districts viz. Tumkur, Chitradurga and Hassan are from South Karnataka.

In case of CHCs all 5 higher order districts viz. Chikkaballapur, Bangalore rural, Bangalore urban, Hassan and Udupi are from South Karnataka. In the lower order, the 5 districts, except Bijapur and Dharwad, the remaining districts (Kolar, Chamarajanagar and Tumkur) are from South Karnataka.

More number of PHCs are situated in Bangalore rural, Bangalore urban, Chikkaballapur, Dakshina Kannada and Udupi, these all are from South Karnataka. Among the lower order districts except Kolar, the remaining districts viz. Bijapur, Koppal, Gulbarga and Uttar Kannada are from South Karnataka.

Higher number of beds (among top 5 districts) can be observed in the 4 districts of South Karnataka (Bangalore urban, Bangalore 
rural, Chikkaballapur and Mysore), 1 district (Dharwad) in North Karnataka. Except Chamarajanagar of South Karnataka, the remaining districts namely Bagalkot, Bijapur, Gulbarga and Koppal are from North Karnataka.

\section{Health Status}

Excluding Belgaum, the remaining districts viz. Udupi, Dakshina Kannada, Shimoga, Bangalore urban are from South Karnataka in case of the top 5 districts in LEB. All the lower order 5 districts (Bagalkot, Dharwad, Haveri, Bijapur and Gadag) are from North Karnataka.

With regard to the IMR, the top five districts viz. Dharwad, Haveri, Bijapur, Gadag and Gulbarga are from North Karnataka. In the lower order, except, Belgaum, the remaining districts (Udupi, Dakshina Kannada, Shimoga, Bangalore urban and Bangalore rural) are from South Karnataka.

The analysis clearly shows that with respect to all the health infrastructure facilities, North Karnataka districts have remained lower, which has resulted in their poor health status. Different health indicators show different status of health condition. Hence considering all the indicators and constructing the index is a widely used method to analyse the overall condition/status of the health sector. Among the indicators, the Principle Composite Index (PCI) Weighted Indexing (WI), Relativity Index (RI) methods and many others have been used by the analysts. In the present study, the relativity index method and weighted index method have been used to construct the indices. They are presented below,

HII $=\frac{X d}{X s} \quad$ Where, ' $\mathrm{d}$ ' stands for district, ' $\mathrm{s}$ ' state, ' $\mathrm{X}$ ' variable

HSI $=\frac{\text { Actual Value }- \text { Minimum Value }}{\text { Maximum Value }- \text { Minimum Value }}$ 
Table 4: Districtwise Selected Health Infrastructure Facilities in Karnataka, 2010

\begin{tabular}{|c|c|c|c|c|c|c|c|c|c|c|c|c|c|c|c|c|c|}
\hline \multirow{3}{*}{ 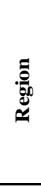 } & \multirow{3}{*}{ Name } & \multicolumn{8}{|c|}{ Per 10 Lakh Population } & \multicolumn{8}{|c|}{ Per 10 thousand sq KM Area } \\
\hline & & \multicolumn{2}{|c|}{$\begin{array}{c}\text { District and } \\
\text { other } \\
\text { Hospitals }\end{array}$} & \multicolumn{2}{|c|}{$\begin{array}{c}\text { Community } \\
\text { Health Centres }\end{array}$} & \multicolumn{2}{|c|}{$\begin{array}{c}\text { PHCs and Sub } \\
\text { Centres }\end{array}$} & \multicolumn{2}{|c|}{ Total Beds } & \multicolumn{2}{|c|}{$\begin{array}{c}\text { District and } \\
\text { other } \\
\text { Hospitals }\end{array}$} & \multicolumn{2}{|c|}{$\begin{array}{c}\text { Community } \\
\text { Health Centres }\end{array}$} & \multicolumn{2}{|c|}{$\begin{array}{l}\text { PHCs and } \\
\text { Sub Centres }\end{array}$} & \multicolumn{2}{|c|}{ Total Beds } \\
\hline & & Actual & Rank & Actual & Rank & Actual & Rank & Actual & Rank & Actual & Rank & Actual & Rank & Actual & Rank & Actual & Rank \\
\hline \multirow{12}{*}{ है } & Bagalkot & 0.5 & 25 & 6.3 & 11 & 143 & 23 & 586 & 28 & 2 & 24 & 18 & 14 & 411 & 23 & 1680 & 27 \\
\hline & Belgaum & 0.2 & 29 & 5 & 21 & 144 & 22 & 602 & 27 & 1 & 28 & 18 & 15 & 511 & 17 & 2144 & 17 \\
\hline & Bellary & 2.4 & 4 & 5.1 & 20 & 135 & 25 & 1065 & 9 & 7 & 5 & 15 & 18 & 407 & 24 & 3202 & 10 \\
\hline & Bidar & 0.6 & 23 & 5.9 & 14 & 168 & 19 & 724 & 21 & 2 & 21 & 18 & 13 & 523 & 16 & 2258 & 14 \\
\hline & Bijapur & 0.9 & 19 & 5.5 & 19 & 160 & 21 & 678 & 23 & 2 & 20 & 11 & 26 & 333 & 25 & 1407 & 28 \\
\hline & Dharwad & 2.2 & 5 & 1.6 & 28 & 114 & 28 & 1030 & 10 & 9 & 3 & 7 & 29 & 499 & 18 & 4496 & 5 \\
\hline & Gadag & 2.8 & 3 & 5.6 & 17 & 196 & 15 & 805 & 16 & 6 & 6 & 13 & 23 & 449 & 20 & 1842 & 24 \\
\hline & Gulbarga & 0.3 & 28 & 8 & 7 & 135 & 26 & 765 & 18 & 1 & 29 & 18 & 12 & 311 & 27 & 1763 & 26 \\
\hline & Haveri & 0.6 & 21 & 7 & 9 & 227 & 11 & 716 & 22 & 2 & 18 & 23 & 7 & 738 & 10 & 2331 & 13 \\
\hline & Koppal & 1.4 & 10 & 7.9 & 8 & 165 & 20 & 644 & 24 & 2 & 16 & 13 & 21 & 271 & 28 & 1059 & 29 \\
\hline & Raichur & 0.5 & 26 & 4.7 & 24 & 129 & 27 & 637 & 25 & 2 & 22 & 16 & 17 & 448 & 21 & 2205 & 16 \\
\hline & $\begin{array}{l}\text { Uttara } \\
\text { Kannada }\end{array}$ & 1.4 & 11 & 9 & 3 & 138 & 24 & 1350 & 3 & 2 & 19 & 13 & 24 & 193 & 29 & 1885 & 22 \\
\hline \multirow{17}{*}{ 音 } & Bangalore & 1.3 & 13 & 0.6 & 29 & 27 & 29 & 518 & 29 & 55 & 1 & 27 & 5 & 1178 & 3 & 22685 & 1 \\
\hline & $\begin{array}{l}\text { Bangalore } \\
\text { Rural }\end{array}$ & 1 & 16 & 3 & 27 & 241 & 8 & 621 & 26 & 11 & 2 & 32 & 2 & 2543 & 1 & 6549 & 3 \\
\hline & \begin{tabular}{|l|} 
Chamarajan \\
agar \\
\end{tabular} & 1 & 17 & 5.9 & 15 & 297 & 5 & 1019 & 12 & 2 & 23 & 11 & 27 & 533 & 15 & 1829 & 25 \\
\hline & \begin{tabular}{|l} 
Chikkaballa \\
pura
\end{tabular} & 0.8 & 20 & 5.6 & 18 & 191 & 16 & 756 & 19 & 8 & 4 & 53 & 1 & 1813 & 2 & 7160 & 2 \\
\hline & \begin{tabular}{|l|} 
Chikmagalu \\
$\mathrm{r}$ \\
\end{tabular} & 1.8 & 6 & 8.8 & 5 & 372 & 2 & 1299 & 4 & 3 & 15 & 14 & 20 & 587 & 12 & 2052 & 20 \\
\hline & Chitradurga & 0.6 & 22 & 9 & 4 & 216 & 13 & 941 & 14 & 1 & 26 & 18 & 16 & 428 & 22 & 1862 & 23 \\
\hline & \begin{tabular}{|l|}
$\begin{array}{l}\text { Dakshina } \\
\text { Kannada }\end{array}$ \\
\end{tabular} & 1.4 & 9 & 4.8 & 23 & 239 & 9 & 964 & 13 & 6 & 8 & 21 & 9 & 1028 & 4 & 4148 & 6 \\
\hline & Davanagere & 1.5 & 8 & 4.6 & 25 & 202 & 14 & 1077 & 7 & 5 & 11 & 15 & 19 & 655 & 11 & 3483 & 9 \\
\hline & Hassan & 0.6 & 24 & 11.8 & 2 & 307 & 4 & 1572 & 2 & 1 & 25 & 31 & 3 & 800 & 9 & 4097 & 7 \\
\hline & Kodagu & 3.6 & 1 & 14.4 & 1 & 397 & 1 & 2176 & 1 & 5 & 12 & 20 & 11 & 536 & 14 & 2942 & 11 \\
\hline & Kolar & 3.2 & 2 & 3.9 & 26 & 170 & 18 & 1112 & 6 & 6 & 9 & 7 & 28 & 319 & 26 & 2082 & 19 \\
\hline & Mandya & 1.1 & 15 & 6.1 & 13 & 267 & 7 & 1067 & 8 & 4 & 13 & 22 & 8 & 974 & 6 & 3890 & 8 \\
\hline & Mysore & 1.3 & 12 & 5.7 & 16 & 190 & 17 & 1186 & 5 & 6 & 7 & 27 & 6 & 908 & 7 & 5668 & 4 \\
\hline & Ramanagara & 0.9 & 18 & 6.5 & 10 & 272 & 6 & 738 & 20 & 3 & 14 & 20 & 10 & 827 & 8 & 2248 & 15 \\
\hline & Shimoga & 1.1 & 14 & 6.3 & 12 & 226 & 12 & 1029 & 11 & 2 & 17 & 13 & 22 & 468 & 19 & 2135 & 18 \\
\hline & Tumkur & 0.4 & 27 & 4.8 & 22 & 228 & 10 & 776 & 17 & 1 & 27 & 12 & 25 & 577 & 13 & 1965 & 21 \\
\hline & Udupi & 1.7 & 7 & 8.5 & 6 & 310 & 3 & 861 & 15 & 6 & 10 & 28 & 4 & 1014 & 5 & 2818 & 12 \\
\hline \multirow{3}{*}{$\bar{z}$} & North & 1 & & 5.9 & & 149 & & 775 & & 2.5 & & 15.6 & & 395 & & 2048 & \\
\hline & South & 1.3 & & 4.8 & & 184 & & 902 & & 4.7 & & 18.2 & & 693 & & 3393 & \\
\hline & Karnataka & 1.1 & & 5.3 & & 169 & & 847 & & 4 & & 17 & & 540 & & 2701 & \\
\hline \multirow{3}{*}{ 己 } & North & 76 & & 32 & & 20 & & 29 & & 91 & & 27 & & 33 & & 41 & \\
\hline & South & 63 & & 50 & & 34 & & 37 & & 171 & & 50 & & 62 & & 109 & \\
\hline & Karnataka & 67 & & 3 & & 80 & & 349 & & 10 & & 9 & & 489 & & 3972 & \\
\hline
\end{tabular}

source: Karnataka at a Glance 


\section{Maximum and minimum Values}

Using the method mentioned above, the HII and HSI have been calculated and presented in the below mentioned table. The averages of HII and HSI show that North Karnataka stands lower than the average of the state and that of South Karnataka. The value of HII is 1.14 in South Karnataka whereas it is only 0.86 in North Karnataka. On the other side, the value of HSI in South is 1.02 and in North Karnataka it is 0.96. It is observed that there is a huge gap in HII between the Southern and the Northern districts, while in HSI, it is low.

Regional disparity is measured through coefficient of variation, which has been presented in the table. CV is high in HII (9\%) than HSI (47\%). Regional imbalances within the regions (North or South) show that South Karnataka has higher district disparities than the North Karnataka. Regional disparity is measured through coefficient of variation, which has been presented in the table. CV is high in HII (9\%) than HSI (47\%). Regional imbalances within the regions (North or South) show that South Karnataka has higher district disparities than the North Karnataka.

Based on the Ranks of HII and HIS, the following three conclusions can be drawn: one, Bangalore Urban tops in HII and Dakshina Kannada district tops in HSI. Both these districts are from South Karnataka; two, Dharwad and Bagalkot stand last in positions, respectively with regard to the HII and HSI respectively. All the top 5 districts in HII are from South Karnataka viz. Bangalore Urban, Bangalore rural, Chikkaballapur, Kodagu and Udupi, whereas, all the bottom 5 districts are from North Karnataka viz. Bagalkot, Belgaum, Bijapur, Gulbarga and Raichur; and three, among the top 5 districts in HSI, except Belgaum, the remaining districts viz. Dakshina Kannada, Udupi, Shimoga and Bangalore urban are from South Karnataka. 
Table 5: Districtwise Selected Health Status in Karnataka, 2010;

\begin{tabular}{|c|c|c|c|c|c|}
\hline \multirow[b]{2}{*}{ Region } & \multirow[b]{2}{*}{ District } & \multicolumn{2}{|c|}{ HII } & \multirow{2}{*}{$\frac{\text { HSI }}{\text { Value }}$} & \multirow[b]{2}{*}{ Rank } \\
\hline & & Value & Rank & & \\
\hline \multirow{12}{*}{$\begin{array}{l}\text { Ẽ் } \\
\text { Z } \\
\text { Z }\end{array}$} & Bagalkot & 0.76 & 25 & 0.89 & 25 \\
\hline & Belgaum & 0.71 & 29 & 1.13 & 3 \\
\hline & Bellary & 1.24 & 11 & 1.02 & 10 \\
\hline & Bidar & 0.86 & 22 & 0.9 & 23 \\
\hline & Bijapur & 0.74 & 27 & 0.89 & 28 \\
\hline & Dharwad & 1.22 & 12 & 0.87 & 29 \\
\hline & Gadag & 1.22 & 13 & 0.89 & 24 \\
\hline & Gulbarga & 0.74 & 28 & 0.89 & 27 \\
\hline & Haveri & 1.03 & 17 & 0.89 & 26 \\
\hline & Koppal & 0.85 & 23 & 0.91 & 22 \\
\hline & Raichur & 0.75 & 26 & 0.95 & 17 \\
\hline & Uttara Kannada & 0.96 & 20 & 0.94 & 18 \\
\hline \multirow{17}{*}{$\begin{array}{l}\text { Ẽ } \\
\text { ¿ }\end{array}$} & Bangalore & 3.68 & 1 & 1.12 & 5 \\
\hline & Bangalore Rural & 1.95 & 2 & 1.08 & 7 \\
\hline & Chamarajanagar & 0.96 & 19 & 0.96 & 14 \\
\hline & Chikkaballapura & 1.88 & 4 & 1.09 & 6 \\
\hline & Chikmagalur & 1.3 & 10 & 0.92 & 20 \\
\hline & Chitradurga & 0.94 & 21 & 1 & 12 \\
\hline & $\begin{array}{l}\text { Dakshina } \\
\text { Kannada }\end{array}$ & 1.39 & 8 & 1.14 & 1 \\
\hline & Davanagere & 1.18 & 14 & 1.03 & 9 \\
\hline & Hassan & 1.45 & 7 & 0.96 & 15 \\
\hline & Kodagu & 1.93 & 3 & 0.92 & 19 \\
\hline & Kolar & 1.18 & 15 & 0.95 & 16 \\
\hline & Mandya & 1.33 & 9 & 0.92 & 21 \\
\hline & Mysore & 1.49 & 6 & 0.98 & 13 \\
\hline & Ramanagara & 1.1 & 16 & 1.05 & 8 \\
\hline & Shimoga & 0.98 & 18 & 1.12 & 4 \\
\hline & Tumkur & 0.79 & 24 & 1.02 & 11 \\
\hline & Udupi & 1.51 & 5 & 1.13 & 2 \\
\hline \multirow{3}{*}{$\bar{Z}$} & North & 0.86 & & 0.92 & \\
\hline & South & 1.14 & & 1.02 & \\
\hline & Karnataka & 1 & & 1 & \\
\hline \multirow{3}{*}{$\vec{u}$} & North & 22.3 & & 8 & \\
\hline & South & 45.2 & & 7.6 & \\
\hline & Karnataka & 47.2 & & 9 & \\
\hline
\end{tabular}


In addition to the construction of indices, another exercise has also been made to present the averages of HII and HSI through scatter diagram. For the analytical purpose the districts have been categorised into 4 groups namely,

\begin{tabular}{|l|l|}
\hline I Best & High HIS and High HII \\
\hline II Good (Lopsided HIS) & High HIS and Low HII \\
\hline III Low Lopside HII & High HIS and High HII \\
\hline IV Bad & High HIS and Low HII \\
\hline
\end{tabular}

Fig.1

In fig 1, it is observed that Bangalore urban, Bangalore rural, Chikkaballapur, Udupi, Bellary, Davangere Ramanagar and Dakshina Kannada are considered as the best, because, values of HII and HSI in these districts are higher than the average of state value.

Tumkur, Shimoga, Belgaum and Davangere are those districts whose performances are considered good because, even though they have lower health infrastructure, the health status of these districts is above the average of the state HSI value.

Mysore, Kodagu, Hassan, Dharwad, Gadag Mandya, Haveri and Kolar are in the lower (third) category, whereas, HII is above the state average but their HSI is lower than the state average. In such situation, planners and policy makers have to think what the problems are with service delivery, in the health sector.

In the last category, there are 8 districts. In this category, the districts are below the state average in both HII and HSI. Districts in this category are Gulbarga, Bagalkot, Koppal, Uttar Kannada, Raichur, Bidar, Bijapur and Chamarajanagar. Except Chamarajanagar, all are from North Karnataka.

The district categories especially in North Karnataka show the ignorance of the Government in providing the health facilities to the people. 


\begin{tabular}{|c|c|c|c|c|c|}
\hline \multirow[b]{2}{*}{ Region } & \multirow[b]{2}{*}{ District } & \multicolumn{2}{|l|}{ HII } & \multirow{2}{*}{$\begin{array}{l}\text { HSI } \\
\text { Value }\end{array}$} & \multirow[b]{2}{*}{ Rank } \\
\hline & & Value & Rank & & \\
\hline \multirow{12}{*}{ 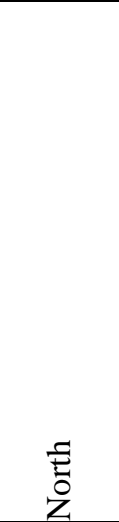 } & Bagalkot & 0.76 & 25 & 0.89 & 25 \\
\hline & Belgaum & 0.71 & 29 & 1.13 & 3 \\
\hline & Bellary & 1.24 & 11 & 1.02 & 10 \\
\hline & Bidar & 0.86 & 22 & 0.9 & 23 \\
\hline & Bijapur & 0.74 & 27 & 0.89 & 28 \\
\hline & Dharwad & 1.22 & 12 & 0.87 & 29 \\
\hline & Gadag & 1.22 & 13 & 0.89 & 24 \\
\hline & Gulbarga & 0.74 & 28 & 0.89 & 27 \\
\hline & Haveri & 1.03 & 17 & 0.89 & 26 \\
\hline & Koppal & 0.85 & 23 & 0.91 & 22 \\
\hline & Raichur & 0.75 & 26 & 0.95 & 17 \\
\hline & Uttara Kannada & 0.96 & 20 & 0.94 & 18 \\
\hline \multirow{17}{*}{ 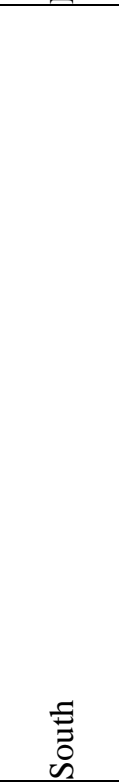 } & Bangalore & 3.68 & 1 & 1.12 & 5 \\
\hline & Bangalore Rural & 1.95 & 2 & 1.08 & 7 \\
\hline & Chamarajanagar & 0.96 & 19 & 0.96 & 14 \\
\hline & Chikkaballapura & 1.88 & 4 & 1.09 & 6 \\
\hline & Chikmagalur & 1.3 & 10 & 0.92 & 20 \\
\hline & Chitradurga & 0.94 & 21 & 1 & 12 \\
\hline & $\begin{array}{l}\text { Dakshina } \\
\text { Kannada }\end{array}$ & 1.39 & 8 & 1.14 & 1 \\
\hline & Davanagere & 1.18 & 14 & 1.03 & 9 \\
\hline & Hassan & 1.45 & 7 & 0.96 & 15 \\
\hline & Kodagu & 1.93 & 3 & 0.92 & 19 \\
\hline & Kolar & 1.18 & 15 & 0.95 & 16 \\
\hline & Mandya & 1.33 & 9 & 0.92 & 21 \\
\hline & Mysore & 1.49 & 6 & 0.98 & 13 \\
\hline & Ramanagara & 1.1 & 16 & 1.05 & 8 \\
\hline & Shimoga & 0.98 & 18 & 1.12 & 4 \\
\hline & Tumkur & 0.79 & 24 & 1.02 & 11 \\
\hline & Udupi & 1.51 & 5 & 1.13 & 2 \\
\hline \multirow[b]{3}{*}{$\overline{2}$} & North & 0.86 & & 0.92 & \\
\hline & South & 1.14 & & 1.02 & \\
\hline & Karnataka & 1 & & 1 & \\
\hline \multirow[b]{3}{*}{ 己 } & North & 22.3 & & 8 & \\
\hline & South & 45.2 & & 7.6 & \\
\hline & Karnataka & 47.2 & & 9 & \\
\hline
\end{tabular}

Source: Karnataka at a Glance 


\section{Role of Government}

In India, due to poor financial conditions, it is difficult to expect the people to spend a lot from their pockets on health. People with sound financial background can spend good amount of money on health. But the poor cannot spend much on health. Most of the poor people in India are from the village and they are daily wage labourers. Their employment is seasonal and due to disguised unemployment, they are underpaid. Hence most of their income is spent on food, clothes and other basic amenities. And many a times, they face acute scarcity for these things. Therefore, the Government expenditure is not only necessary but also indispensable or sine qua non. The Karnataka state Government has been implementing various policy/programmes to improve the health condition of the people. It has been allocating a huge amount of money through budget over a period of time. Information related to health expenditure in Karnataka has been presented in Table. 7 It shows total health expenditure and per capita health expenditure at current and constant prices (2004-05 prices), along with this, health expenditure as a share of total budgetary expenditure and as a share of NSDP (Net State Domestic Product).

HII Fig. 1: Categorisation of the Districts above and below Average of HII and HSI of the State

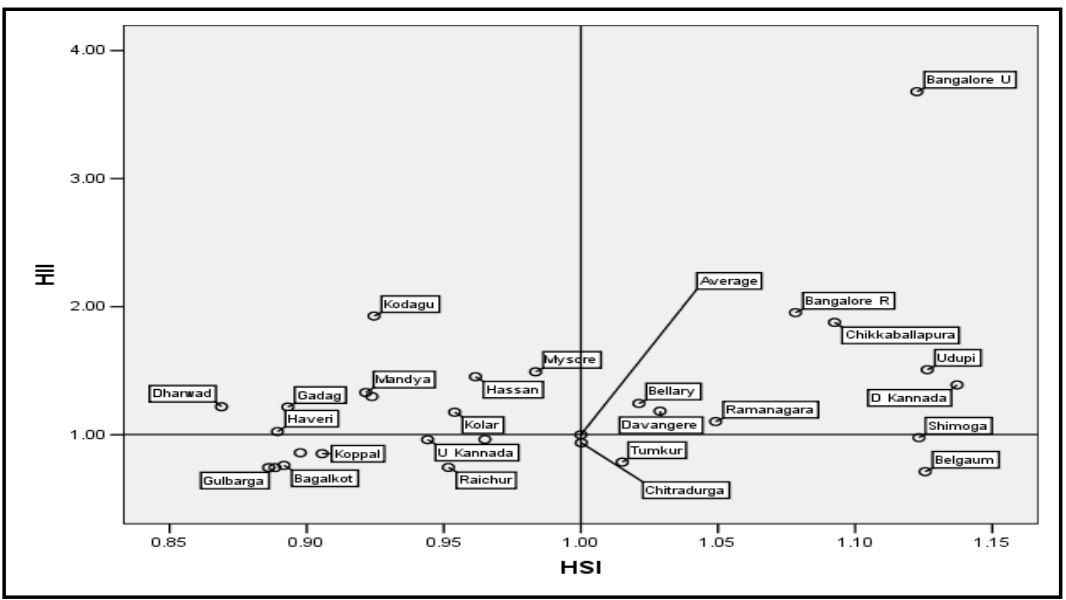

Source: Computed from the data available from Karnataka at a Glance 
Health expenditure of the state during 1990-91 at current prices is Rs 38,729 lakhs, which, increased to Rs 598058 lakhs, it means that there is a 15 times increase in the 20 years of time period, which is 12 times in per capita term. This impressive picture gets offset when we see these data in per capita real (2004-05 prices) prices. In per capita real term, health expenditure has increased only 3.6 times, i.e. per capita health expenditure at constant prices has increased from Rs. 215 in 1990-91 to Rs. 777 in 2009-10.

Observing the present health condition of Karnataka, this expenditure is significantly lower. On the other hand, health expenditure as a share of total expenditure is also lower. In the reference period, the health expenditure as a share of total expenditure is between 6 per cent and 11 per cent. In 1990-91 it was 7.8 per cent, which increased to 10.7 percent. In the following years, it started decreasing and reached 6.1 per cent during 2004-05, which is the lowest among the 20 years of the selected time period.

Further, in the latter years, it started increasing and reached 10.5 per cent in 2009-10. Health Expenditure as a share of NSDP is presented in the above mentioned table. It is also observed from the table that the health expenditure as a share of NSDP was 1.5 per cent, which increased to 1.9 per cent in 1990-00. (But it has not been maintained and decreased to 1.3 per cent in 2004-05). Further, it has shown an increasing trend and reached to 2 per cent.

Government expenditure has been categorised in capital and revenue accounts. It is a known fact that both the capital and revenue expenditure are important for the development of the sector. Capital expenditure plays a very important role because revenue expenditure is mostly devoted on the salary of the staff and the maintenance expenses, whereas, the capital expenditure is spent on creation of new assets like building equipments and so on. The Composition of capital and revenue health expenditure of the Karnataka state has been presented in Figure 2. 
Table 7: Health Expenditure in Karnataka from 1990-91 to 2009-10

\begin{tabular}{|c|c|c|c|c|c|c|}
\hline \multirow{2}{*}{ Year } & \multicolumn{2}{|c|}{ Current Prices } & \multicolumn{2}{c|}{ Constant Prices } & $\begin{array}{c}\text { As share } \\
\text { of NSDP }\end{array}$ & $\begin{array}{c}\text { As share of } \\
\text { Total Expns }\end{array}$ \\
\cline { 2 - 5 } & Actual & Per Capita & Actual & Per capita & 1.5 & 7.8 \\
\hline $1990-91$ & 38729 & 87 & 96241 & 215 & 1.4 & 7.4 \\
\hline $1991-92$ & 46484 & 102 & 100066 & 220 & 1.4 & 7.1 \\
\hline $1992-93$ & 50062 & 109 & 101100 & 219 & 1.3 & 6.9 \\
\hline $1993-94$ & 55578 & 118 & 103674 & 220 & 1.4 & 7.9 \\
\hline $1994-95$ & 69793 & 145 & 117651 & 245 & 1.4 & 7.8 \\
\hline $1995-96$ & 80914 & 165 & 123619 & 252 & 1.3 & 7.3 \\
\hline $1996-97$ & 87668 & 176 & 125984 & 253 & 1.6 & 9.4 \\
\hline $1997-98$ & 118544 & 235 & 162259 & 321 & 1.7 & 10.7 \\
\hline $1998-99$ & 158574 & 310 & 202673 & 396 & 1.9 & 10.5 \\
\hline $1999-00$ & 187354 & 362 & 233317 & 450 & 1.7 & 8.9 \\
\hline $2000-01$ & 174872 & 333 & 205992 & 392 & 1.6 & 7.8 \\
\hline $2001-02$ & 171827 & 326 & 200763 & 381 & 1.3 & 6.3 \\
\hline $2003-03$ & 152100 & 285 & 174872 & 328 & 1.4 & 6.4 \\
\hline $2004-05$ & 172591 & 320 & 187535 & 347 & 1.3 & 6.1 \\
\hline $2005-06$ & 192637 & 352 & 192637 & 352 & 1.7 & 8.2 \\
\hline $2006-07$ & 301532 & 544 & 267677 & 483 & 1.5 & 7.3 \\
\hline $2007-08$ & 456758 & 817 & 383830 & 686 & 1.9 & 10 \\
\hline $2008-09$ & 541233 & 959 & 422471 & 749 & 2 & 10.6 \\
\hline $2009-10$ & 598058 & 1050 & 442130 & 777 & 2 & 10.5 \\
\hline $\begin{array}{l}\text { Growth } \\
\text { Rate }\end{array}$ & 14.36 & 12.94 & 7.97 & 6.63 & 1.45 & \\
\hline & & 530 & 272777 & 499 & & \\
\hline
\end{tabular}

Source: Various Issues of -Study on State Finances, RBI

It is observed that the revenue expenditure is very high compared to that of capital expenditure, which is a very common phenomenon because, in the health sector, creation of assets is important in general and maintenance in particular. It is also seen that the State's capital expenditure was very less i.e. Rs. 657 lakhss during 1990-91 (1.7 per cent) as against Rs. 37415 lakhss of revenue expenditure (98.3 per cent) during 1998-99.

This composition was 19.5 per cent and 79.5 per cent for capital and revenue respectively, further, capital expenditure decreased to 6.1 per cent during 2002-03, again started increasing in the later years and reached to, 35 per cent in 2009-10. It is observed that the capital expenditure in the recent years has increased significantly due to the implementation of various health programmes like National Rural Health Mission (NRHM), Health For All, Vajapayee Arogya 
Shree and so on (please see figure 1 and appendix table 1 for further details).

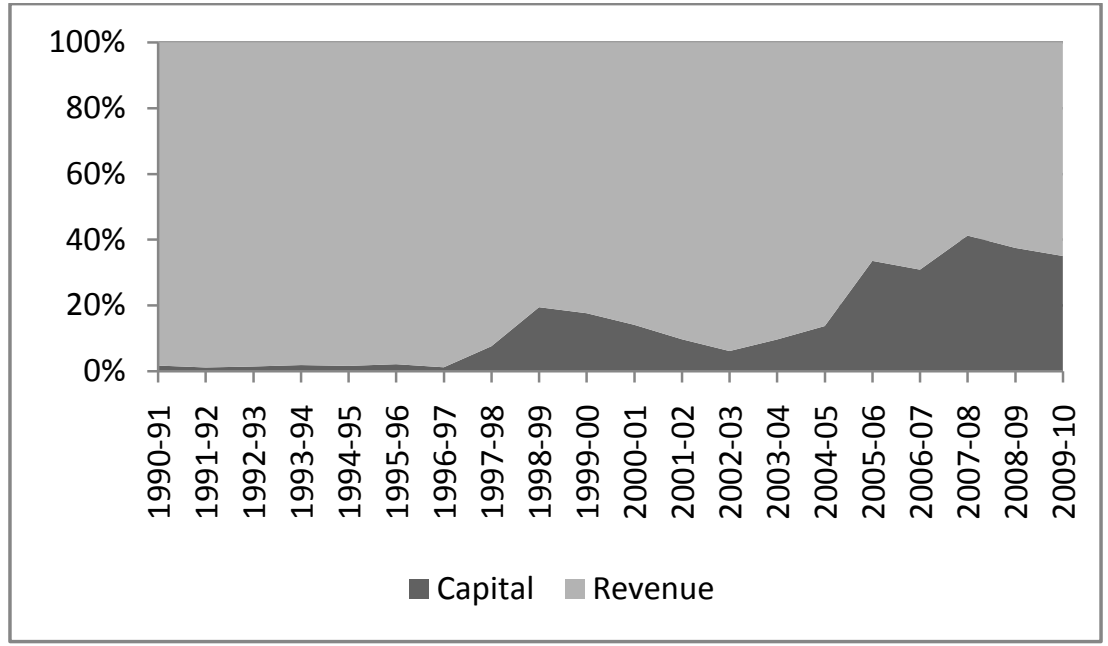

Fig. 2: Trends of Capital and Revenue Expenditure on Health in Karnataka from 1990-91 to 2009-10 Source: Various Issues of Study on State Finances, RBI

Figure 2 shows the composition of health expenditure on different sectors. In the present study, the health expenditure includes the expenditure on 'medical and public health', 'family welfare', 'water supply and sanitation' and expenditure on 'nutrition'. Among these, the expenditure on 'medical and public health' has the highest share, which was 64 per cent in 1990-91 and decreased to 35 per cent in 2009-10. Expenditure on 'family welfare' was negligible i.e. less than 1 per cent, which increased to 12.8 per cent in 2001-02. Further, it started decreasing to reach 5 per cent of the total health expenditure to Rs. 29,696 lakhs.

Another sector in the health expenditure is 'water supply and sanitation'. Though this sector is not directly related to the health sector, it helps to improve the health condition of the people. Polluted water is the major source for most of the diseases. Availability of safe drinking water makes people stay away from illness. Clean environment is also necessary for the good health condition. 


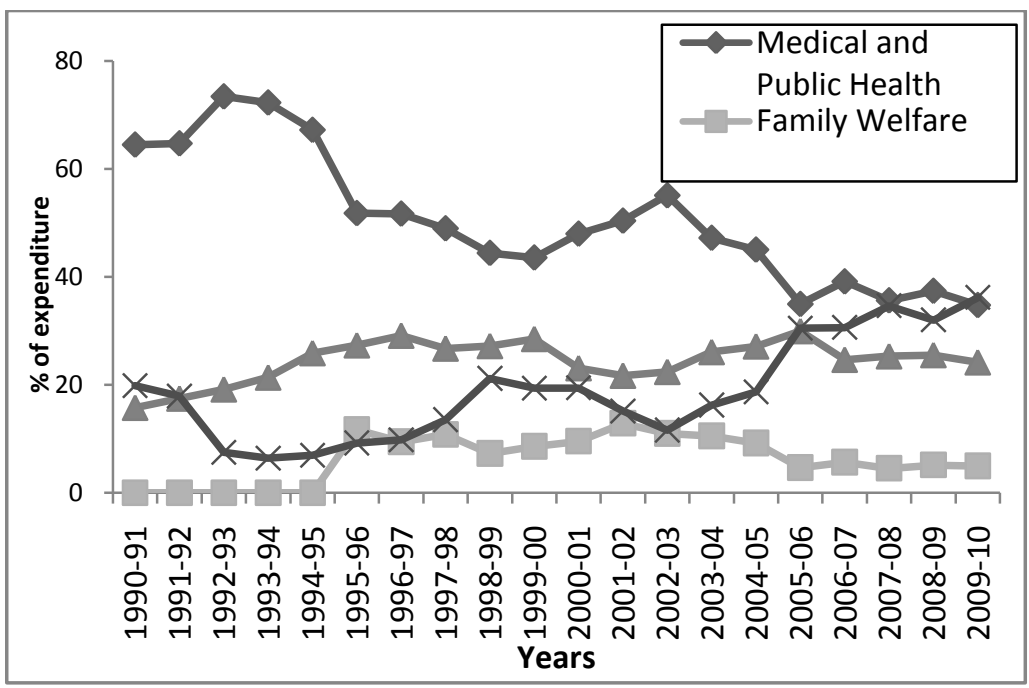

Fig. 3: Trends of Composition of Health Expenditure in Karnataka from 1990-91 to 2009-10 Source: Various Issues of Study on State Finances, RBI

Hence, spending on sanitation is also an important thing. In 199091, the expenditure on water supply and sanitation was Rs. 6,086 lakhs which was increased to Rs. 1,44,488 lakhs in 2009-10. The Share of this sector is between 16 and 30 per cent during the 20 years of the study period. In the year 1990-91, the share of spending on this sector was 10 per cent, which increased to 30 per cent in 2002-03 and started decreasing to reach 24 per cent in 2009-10. Further, nutrition should also be given importance, in the health sectors as it plays an important role in the development of the health condition of the community. A well nourished body would be protected from all diseases. The Expenditure on this sector was Rs. 7,684 lakhs in 1990-91, which was increased to Rs. 2,16,232 lakhs in 2009-10. The share of spending on this sector to the total health expenditure was 20 per cent in 1990-91, which was decreased to 6 per cent in 1993-94. The trend of spending on this sector started to increase afterwards and reached 35 per cent in 2009-10. Rapid spending on this sector has to be admired (please see figure 3 and appendix table 2). 


\section{Conclusions}

Health is an important basic need. Healthy people are the real wealth of the nation. With regard to the health infrastructure and health status, though India has made significant improvements, it is comparatively lagging behind many developed and developing countries. Karnataka is closer to the average of India, in most of the health status and health facilities, but compared to the states like Kerala, it stands too low. The most striking problem related to the health infrastructure and health status arises out of the regional imbalance. This study shows that Gulbarga and Belgaum divisions of Karnataka show a poor status in health infrastructure and health status. Among these, the Gulbarga division (means Hyderabad Karnataka) lies in the lower position. It is well know that Hyderabad Karnataka is under developed in most of the sectors compared to the rest of the regions. Lower health infrastructure facilities in this region clearly indicate the negligence of the Government intervention/interest to develop basic infrastructure facilities in this region. For better health, health facilities should be improved. For better health facilities, public health expenditure is very important. At present, the Karnataka Government is spending very less amount of money on health that is 2 per cent of the NSDP, which has to be increased. Of this expenditure, the capital expenditure is increasing over the period of time very rapidly which is to be admired. In Karnataka, to improve the health facilities many programmes are being implemented, among them NRHM is important, which has to be implemented more meaningfully. The increasing of public expenditure alone cannot serve the purpose, unless it is properly used for delivering quality infrastructure and good service mechanisation.

\section{References}

Dadibhavi, R. V., \& Bagalkoti, S. T. (1994). Inter-state disparities in health status in India. Yojana ,41(1)

Government of India, (2011). India human development report

Government of Karnataka, (2005). Karnataka human development report

UNDP, (2011). Human development report

Government of Karnataka. Various issues of Karnataka at a glance 
Appendix Table 1: Districtwise Health Number of Different Health Infrastructure Facilities, Population and Area Sq. KMs, 2010.

\begin{tabular}{|c|c|c|c|c|c|c|}
\hline District & $\begin{array}{l}\text { District } \\
\text { and other } \\
\text { Hospitals }\end{array}$ & $\begin{array}{l}\text { Community } \\
\text { Health } \\
\text { Centres }\end{array}$ & $\begin{array}{l}\text { PHCs } \\
\text { and Sub } \\
\text { Centres }\end{array}$ & $\begin{array}{l}\text { Total } \\
\text { Beds }\end{array}$ & Population & $\begin{array}{l}\text { Area (Sq. } \\
\text { Kms.) }\end{array}$ \\
\hline Bagalkot & 1 & 12 & 271 & 1108 & 1890826 & 6594 \\
\hline Belgaum & 1 & 24 & 686 & 2876 & 4778439 & 13415 \\
\hline Bellary & 6 & 13 & 343 & 2696 & 2532383 & 8419 \\
\hline Bidar & 1 & 10 & 285 & 1230 & 1700018 & 5448 \\
\hline Bijapur & 2 & 12 & 349 & 1474 & 2175102 & 10475 \\
\hline Dharwad & 4 & 3 & 211 & 1902 & 1846993 & 4230 \\
\hline Gadag & 3 & 6 & 209 & 858 & 1065235 & 4657 \\
\hline Gulbarga & 1 & 30 & 505 & 2860 & 3737877 & 16224 \\
\hline Haveri & 1 & 11 & 358 & 1131 & 1580506 & 4851 \\
\hline Koppal & 2 & 11 & 229 & 896 & 1391292 & 8458 \\
\hline Raichur & 1 & 9 & 249 & 1226 & 1924773 & 5559 \\
\hline Uttara Kannada & 2 & 13 & 199 & 1940 & 1436847 & 10291 \\
\hline Bangalore & 12 & 6 & 258 & 4968 & 9588910 & 2190 \\
\hline Bangalore Rural & 1 & 3 & 238 & 613 & 987257 & 936 \\
\hline Chamarajanagar & 1 & 6 & 303 & 1040 & 1020962 & 5685 \\
\hline Chikkaballapura & 1 & 7 & 240 & 948 & 1254377 & 1324 \\
\hline Chikmagalur & 2 & 10 & 423 & 1478 & 1137753 & 7201 \\
\hline Chitradurga & 1 & 15 & 359 & 1562 & 1660378 & 8388 \\
\hline Dakshina Kannada & 3 & 10 & 498 & 2009 & 2083625 & 4843 \\
\hline Davanagere & 3 & 9 & 394 & 2096 & 1946905 & 6018 \\
\hline Hassan & 1 & 21 & 545 & 2792 & 1776221 & 6814 \\
\hline Kodagu & 2 & 8 & 220 & 1207 & 554762 & 4102 \\
\hline Kolar & 5 & 6 & 262 & 1712 & 1540231 & 8223 \\
\hline Mandya & 2 & 11 & 483 & 1930 & 1808680 & 4961 \\
\hline Mysore & 4 & 17 & 569 & 3553 & 2994744 & 6269 \\
\hline Ramanagara & 1 & 7 & 294 & 799 & 1082739 & 3555 \\
\hline Shimoga & 2 & 11 & 396 & 1807 & 1755512 & 8465 \\
\hline Tumkur & 1 & 13 & 612 & 2082 & 2681449 & 10598 \\
\hline Udupi & 2 & 10 & 365 & 1014 & 1177908 & 3598 \\
\hline North & 25 & 154 & 3894 & 20197 & 26060291 & 98621 \\
\hline South & 44 & 170 & 6459 & 31610 & 35052413 & 93170 \\
\hline Karnataka & 69 & 324 & 10353 & 51807 & 61130704 & 191791 \\
\hline
\end{tabular}

Source: Karnataka at a Glance 
Appendix Table 2: Districtwise Normalised Indicators on Health Infrastructure Facilities, 2010

\begin{tabular}{|c|c|c|c|c|c|c|c|c|c|c|}
\hline Name & District & Community & PHCs and & Total & District & Community & PHCs & Total & Index & Index \\
\hline Bagalkot & 0.47 & 12 & 0.85 & 0.69 & 0.42 & \begin{tabular}{r|}
108 \\
\end{tabular} & 0.76 & 0.62 & 0.76 & 25 \\
\hline Belgaum & 0.19 & 0.95 & 0.85 & 0.71 & 021 & 1.06 & 0.95 & 0.79 & 0.71 & 29 \\
\hline Bellary & 21 & 0.97 & 0.8 & 126 & 1.98 & 0.91 & 0.75 & 1.19 & 124 & 11 \\
\hline Bidar & 0.52 & 1.11 & 0.99 & 0.85 & 0.51 & 1.09 & 0.97 & 0.84 & 0.86 & 27 \\
\hline Bijapur & 0.81 & 104 & 0.95 & 0.8 & 0.53 & 0.68 & 0.62 & 0.52 & 0.74 & 27 \\
\hline Dharwad & 1.92 & 031 & 0.67 & 12 & 2.63 & 0.42 & 0.92 & 166 & 122 & 12 \\
\hline Gadag & 25 & 106 & 116 & 0.95 & 179 & 0.76 & 0.83 & 0.68 & 122 & 13 \\
\hline Gulbarga & 024 & 151 & 0.8 & 0.9 & 0.17 & 109 & 0.58 & 0.65 & 0.74 & 28 \\
\hline Haveri & 0.56 & 131 & 134 & 0.84 & 0.57 & 134 & 137 & 0.86 & 103 & 17 \\
\hline Koppal & 127 & 1.49 & 0.97 & 0.76 & 0.66 & 0.77 & 0.5 & 0.39 & 0.85 & 23 \\
\hline Raichur & 0.46 & 0.88 & 0.76 & 0.75 & 0.5 & 0.96 & 0.83 & 0.82 & 0.75 & 26 \\
\hline Uttara Kannada & 123 & 171 & 0.82 & 159 & 0.54 & 0.75 & 0.36 & 0.7 & 0.96 & 20 \\
\hline Bangalore & 111 & 0.12 & 0.16 & 0.61 & 1523 & 1.62 & 218 & 8.4 & 3.68 & 1 \\
\hline Bangalore Rural & 0.9 & 0.57 & 142 & 0.73 & 2.97 & 19 & 471 & 242 & 195 & 2 \\
\hline Chamarajanagar & 0.87 & 1.11 & 175 & 12 & 0.49 & 0.62 & 0.99 & 0.68 & 0.96 & 19 \\
\hline Chikkaballapura & 0.71 & 1.05 & 113 & 0.89 & 21 & 3.13 & 336 & 265 & 188 & 4 \\
\hline Chikmagalur & 156 & 1.66 & 22 & 153 & 0.77 & 0.82 & 1.09 & 0.76 & 13 & 10 \\
\hline Chitradurga & 0.53 & 17 & 128 & 1.11 & 0.33 & 1.06 & 0.79 & 0.69 & 0.94 & 21 \\
\hline Dakshina Kannada & 128 & 0.91 & 141 & 1.14 & 1.72 & 12 & 19 & 154 & 139 & 8 \\
\hline Davanagere & 137 & 0.87 & 1.19 & 127 & 139 & 0.89 & 121 & 129 & 1.18 & 14 \\
\hline Hassan & 0.5 & 233 & 181 & 185 & 0.41 & 182 & 148 & 152 & 145 & 7 \\
\hline Kodagu & 3.19 & 272 & 234 & 257 & 136 & 1.15 & 0.99 & 1.09 & 193 & 3 \\
\hline Kolar & 288 & 0.73 & 1 & 131 & 1.69 & 0.43 & 0.59 & 0.77 & 1.18 & 15 \\
\hline Mandya & 0.98 & 115 & 158 & 126 & 1.12 & 131 & 1.8 & 1.44 & 133 & 9 \\
\hline Mysore & 1.18 & 107 & 112 & 14 & 177 & 1.61 & 1.68 & 21 & 149 & 6 \\
\hline Ramanagara & 0.82 & 12 & 1.6 & 0.87 & 0.78 & 1.17 & 153 & 0.83 & 1.1 & 16 \\
\hline Shimoga & 1.01 & 1.18 & 133 & 121 & 0.66 & 0.77 & 0.87 & 0.79 & 0.98 & 18 \\
\hline Tumkur & 033 & 0.91 & 135 & 0.92 & 026 & 0.73 & 1.07 & 0.73 & 0.79 & 24 \\
\hline Udupi & 1.5 & 16 & 183 & 1.02 & 155 & 1.65 & 188 & 1.04 & 151 & 5 \\
\hline Karnataka & 1 & 1 & 1 & 1 & 1 & 1 & 1 & 1 & 1 & \\
\hline North & 0.85 & 111 & 0.88 & 0.91 & 0.7 & 0.92 & 0.73 & 0.76 & 0.86 & \\
\hline South & 1.11 & 0.92 & 109 & 106 & 131 & 108 & 128 & 126 & 1.14 & \\
\hline
\end{tabular}

Source: Karnataka at a Glance, 2011 
Appendix Table 3: Districtwise Normalised Indicators on Health

\begin{tabular}{|c|c|c|c|c|c|c|}
\hline \multirow[b]{2}{*}{ Year } & \multicolumn{3}{|c|}{ Actual } & \multicolumn{3}{|c|}{ Composition } \\
\hline & Capital & Revenue & Total & Capital & Revenue & Total \\
\hline 1990-91 & 657 & 37415 & 38072 & 1.7 & 98.3 & 100 \\
\hline 1991-92 & 528 & 45428 & 45956 & 1.1 & 98.9 & 100 \\
\hline 1992-93 & 712 & 48638 & 49350 & 1.4 & 98.6 & 100 \\
\hline 1993-94 & 1025 & 53528 & 54553 & 1.9 & 98.1 & 100 \\
\hline 1994-95 & 1111 & 67571 & 68682 & 1.6 & 98.4 & 100 \\
\hline $1995-96$ & 1692 & 77530 & 79222 & 2.1 & 97.9 & 100 \\
\hline $1996-97$ & 1039 & 85590 & 86629 & 1.2 & 98.8 & 100 \\
\hline $1997-98$ & 8369 & 101806 & 110175 & 7.6 & 92.4 & 100 \\
\hline 1998-99 & 25833 & 106908 & 132741 & 19.5 & 80.5 & 100 \\
\hline 1999-00 & 28090 & 131174 & 159264 & 17.6 & 82.4 & 100 \\
\hline 2000-01 & 21618 & 131636 & 153254 & 14.1 & 85.9 & 100 \\
\hline 2001-02 & 15221 & 141385 & 156606 & 9.7 & 90.3 & 100 \\
\hline 2002-03 & 8798 & 134504 & 143302 & 6.1 & 93.9 & 100 \\
\hline 2003-04 & 15200 & 142191 & 157391 & 9.7 & 90.3 & 100 \\
\hline 2004-05 & 23258 & 146121 & 169379 & 13.7 & 86.3 & 100 \\
\hline $2005-06$ & 72778 & 144199 & 216977 & 33.5 & 66.5 & 100 \\
\hline 2006-07 & 71139 & 159254 & 230393 & 30.9 & 69.1 & 100 \\
\hline 2007-08 & 133333 & 190092 & 323425 & 41.2 & 58.8 & 100 \\
\hline $\begin{array}{l}2008-09 \\
(\mathrm{RE})\end{array}$ & 147564 & 246105 & 393669 & 37.5 & 62.5 & 100 \\
\hline $\begin{array}{l}2009-10 \\
(\mathrm{BE})\end{array}$ & 155161 & 287736 & 442897 & 35 & 65 & 100 \\
\hline $\begin{array}{l}\text { Growth } \\
\text { Rate }\end{array}$ & 37 & 10 & 12 & & & \\
\hline
\end{tabular}




\begin{tabular}{|c|c|c|c|c|c|c|}
\hline \multirow[b]{2}{*}{ Year } & \multicolumn{3}{|c|}{ Actual } & \multicolumn{3}{|c|}{ Composition } \\
\hline & Capital & Revenue & Total & Capital & Revenue & Total \\
\hline $1990-91$ & 657 & 37415 & 38072 & 1.7 & 98.3 & 100 \\
\hline 1991-92 & 528 & 45428 & 45956 & 1.1 & 98.9 & 100 \\
\hline $1992-93$ & 712 & 48638 & 49350 & 1.4 & 98.6 & 100 \\
\hline 1993-94 & 1025 & 53528 & 54553 & 1.9 & 98.1 & 100 \\
\hline $1994-95$ & 1111 & 67571 & 68682 & 1.6 & 98.4 & 100 \\
\hline $1995-96$ & 1692 & 77530 & 79222 & 2.1 & 97.9 & 100 \\
\hline 1996-97 & 1039 & 85590 & 86629 & 1.2 & 98.8 & 100 \\
\hline $1997-98$ & 8369 & 101806 & 110175 & 7.6 & 92.4 & 100 \\
\hline $1998-99$ & 25833 & 106908 & 132741 & 19.5 & 80.5 & 100 \\
\hline 1999-00 & 28090 & 131174 & 159264 & 17.6 & 82.4 & 100 \\
\hline $2000-01$ & 21618 & 131636 & 153254 & 14.1 & 85.9 & 100 \\
\hline $2001-02$ & 15221 & 141385 & 156606 & 9.7 & 90.3 & 100 \\
\hline $2002-03$ & 8798 & 134504 & 143302 & 6.1 & 93.9 & 100 \\
\hline 2003-04 & 15200 & 142191 & 157391 & 9.7 & 90.3 & 100 \\
\hline 2004-05 & 23258 & 146121 & 169379 & 13.7 & 86.3 & 100 \\
\hline $2005-06$ & 72778 & 144199 & 216977 & 33.5 & 66.5 & 100 \\
\hline $2006-07$ & 71139 & 159254 & 230393 & 30.9 & 69.1 & 100 \\
\hline $2007-08$ & 133333 & 190092 & 323425 & 41.2 & 58.8 & 100 \\
\hline $\begin{array}{l}2008-09 \\
\text { (RE) }\end{array}$ & 147564 & 246105 & 393669 & 37.5 & 62.5 & 100 \\
\hline $\begin{array}{l}\text { 2009-10 } \\
\text { (BE) }\end{array}$ & 155161 & 287736 & 442897 & 35 & 65 & 100 \\
\hline $\begin{array}{l}\text { Growth } \\
\text { Rate }\end{array}$ & 37 & 10 & 12 & & & \\
\hline
\end{tabular}

Source: Various Issues of Study of State finances, RBI 
Appendix Table 5: Composition of Health Expenditure of Karnataka from 1990-91 to 2009-10

\begin{tabular}{|c|c|c|c|c|c|c|c|c|c|c|}
\hline \multirow[b]{2}{*}{ Year } & \multicolumn{5}{|c|}{ Actual } & \multicolumn{5}{|c|}{ Composition } \\
\hline & \begin{tabular}{|l} 
Medical \\
and \\
Public \\
Health \\
\end{tabular} & $\begin{array}{l}\text { Family } \\
\text { Welfare }\end{array}$ & \begin{tabular}{|l|} 
Water \\
Supply and \\
Sanitation
\end{tabular} & Nutrition & Health & \begin{tabular}{|l|} 
Medical \\
and Public \\
Health
\end{tabular} & $\begin{array}{l}\text { Family } \\
\text { Welfare }\end{array}$ & \begin{tabular}{|l|} 
Water \\
Supply and \\
Sanitation
\end{tabular} & Nutrition & Health \\
\hline $1990-91$ & 24959 & 0.0002 & 6086 & 7684 & 38729 & 64 & $\mathbf{0}$ & 16 & 20 & 100 \\
\hline \begin{tabular}{|l|}
$1991-92$ \\
\end{tabular} & 30065 & 0.0002 & 8100 & 8319 & 46484 & 65 & 0 & 17 & 18 & 100 \\
\hline $1992-93$ & 36732 & 0.0002 & 9577 & 3753 & 50062 & 73 & 0 & 19 & 7 & 100 \\
\hline 1993-94 & 40149 & 0.0002 & 11856 & 3573 & 55578 & 72 & 0 & 21 & 6 & 100 \\
\hline 1994-95 & 46886 & 0.0002 & 18054 & 4853 & 69793 & 67 & 0 & 26 & 7 & 100 \\
\hline $1995-96$ & 41880 & 9457 & 22108 & 7469 & 80914 & 52 & 11.7 & 27 & 9 & 100 \\
\hline $1996-97$ & 45281 & 8268 & 25525 & 8594 & 87668 & 52 & 9.4 & 29 & 10 & 100 \\
\hline 1997-98 & 58009 & 12797 & 31675 & 16063 & 118544 & 49 & 10.8 & 27 & 14 & 100 \\
\hline 1998-99 & 70375 & 11506 & 43119 & 33574 & 158574 & 44 & 7.3 & 27 & 21 & 100 \\
\hline $1999-00$ & 81553 & 16097 & 53402 & 36302 & 187354 & 44 & 8.6 & 29 & 19 & 100 \\
\hline $2000-01$ & 83837 & 16696 & 40355 & 33984 & 174872 & 48 & 9.5 & 23 & 19 & 100 \\
\hline $2001-02$ & 86524 & 22060 & 37244 & 25999 & 171827 & 50 & 12.8 & 22 & 15 & 100 \\
\hline $2002-03$ & 83732 & 16680 & 34042 & 17646 & 152100 & 55 & 11 & 22 & 12 & 100 \\
\hline 2003-04 & 81415 & 18155 & 45000 & 28021 & 172591 & 47 & 10.5 & 26 & 16 & 100 \\
\hline $2004-05$ & 86673 & 17718 & 52253 & 35993 & 192637 & 45 & 9.2 & 27 & 19 & 100 \\
\hline $2005-06$ & 101175 & 13444 & 86815 & 88321 & 289755 & 35 & 4.6 & 30 & 30 & 100 \\
\hline $2006-07$ & 117899 & 17062 & 74298 & 92273 & 301532 & 39 & 5.7 & 25 & 31 & 100 \\
\hline $2007-08$ & 162593 & 20625 & 115470 & 158070 & 456758 & 36 & 4.5 & 25 & 35 & 100 \\
\hline \begin{tabular}{|l|}
$2008-09$ \\
(RE)
\end{tabular} & 202174 & 27799 & 138049 & 173211 & 541233 & 37 & 5.1 & 26 & 32 & 100 \\
\hline $\begin{array}{l}2009-10 \\
\text { (BE) }\end{array}$ & 207642 & 29696 & 144488 & 216232 & 598058 & 35 & 5 & 24 & 36 & 100 \\
\hline \begin{tabular}{|l|} 
Growth \\
Rate \\
\end{tabular} & 10.3 & 187.2 & 16.1 & 22.3 & 14.4 & & & & & \\
\hline
\end{tabular}

Source: Various Issues of Study of State finances, RBI 